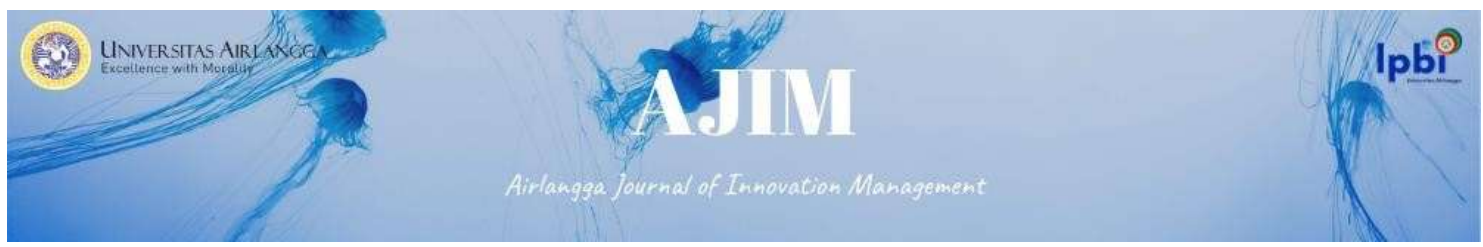

Vol. 1 No.2 Oktober 2020

e-ISSN: 2722-5062

DOI : 10.20473/ajim.v1i1.21607

\title{
THE EFFECTS OF R\&D EXPENDITURES ON ECONOMIC GROWTH IN OECD COUNTRIES
}

\author{
Amanah Abdul Kadir ${ }^{1}$, Wendra Afriana ${ }^{2 *}$, Harry Azhar Azis ${ }^{3}$ \\ Universitas Indonesia ${ }^{1}$ \\ Institute Pertanian Bogor ${ }^{2}$ \\ $\mathrm{BPK} \mathrm{RI}^{3}$ \\ *E-mail korespondensi: weiyacb@gmail.com
}

\begin{abstract}
This study investigates the relationship between $R \& D$ and economic growth in 33 OECD countries. This research uses panel data method. The results showed that there are three independent variables that affect economic growt: gross domestic expenditure on $R \& D$, government research, and internet access. However, gross domestic expenditure on $R \& D$ and government research has a negative impact on economic growth wiith the t-statistics of -2.944775 and -0.203002 , respectively. The $t$-statistic for internet access variable is 2.460783. This shows that only the internet access variable has a positive effect on economic growth. Meanwhile, the variable access to computers from home does not affect economic growth, because the probability is 0.0674 or $>0.05$. These findings do not support the general hypothesis that $R \& D$ expenditures will have a positive impact on economic growth. The research agenda must be clear, substantive and short-term and must be implemented as a consideration in decision making. Therefore, every investment in $R \& D$ spending provides benefits with the hope of creating new innovations, so that the Indonesian economy grows positively.
\end{abstract}

Keywords: R\&D expenditure, Economic Growth, Panel Data.

\begin{abstract}
ABSTRAK
Studi ini mengkaji hubungan antara $R \& D$ dan pertumbuhan ekonomi di 33 negara OECD. Penelitian ini menggunakan metode data panel. Hasil penelitian menunjukkan terdapat tiga variabel independen yang mempengaruhi pertumbuhan ekonomi yaitu pengeluaran domestik bruto untuk $R \& D$, peneliti pemerintah, dan akses internet. Namun untuk pengeluaran domestik bruto untuk $R \& D$ dan peneliti pemerintah, keduanya berdampak negatif terhadap pertumbuhan ekonomi dengan t-statistik masingmasing -2.944775 dan-0.203002. Sedangkan t-statistic untuk variabel akses internet adalah 2.460783. Hal ini menunjukkan bahwa hanya variabel akses internet yang berpengaruh positif terhadap pertumbuhan ekonomi. Sedangkan variabel akses komputer dari rumah tidak mempengaruhi pertumbuhan ekonomi, karena probabilitasnya adalah 0,0674 atau $>0$ 0,05. Temuan ini tidak mendukung hipotesis umum bahwa pengeluaran $R \& D$ akan berdampak positif pada pertumbuhan ekonomi. Agenda penelitian harus jelas, substantif dan berjangka pendek serta harus diimplementasikan sebagai bahan pertimbangan dalam pengambilan keputusan. Sehingga setiap investasi dalam belanja $R \& D$ memberikan manfaat dengan harapan terciptanya inovasi baru, sehingga perekonomian Indonesia tumbuh positif.
\end{abstract}

Kata kunci: Pengeluaran R\&D, Pertumbuhan ekonomi, Panel data. 


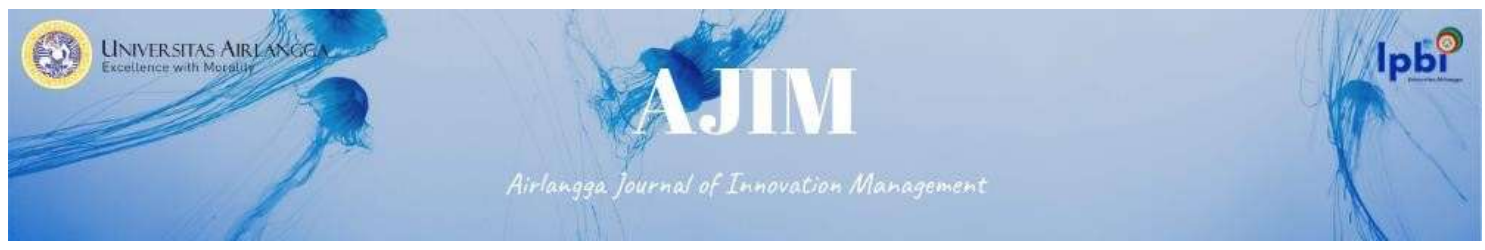

\section{INTRODUCTION}

Since the first industrial revolution marked by the invention of steam engine to invention that combines automation technology with cyber systems and the internet system (Industrial Revolution 4.0) has caused major changes in economic activity. This shows that innovation is one of main attributes of industrial revolution. In the economy, a main key for economy to grow healthy and sustain is within innovation. The idea was first introduced by Joseph Schumpeter (1943) in "Capitalism, Socialism and Democracy" book. Schumpeter said that in order for a country's economic growth to continue to advance and be sustainable, what must be considered is not only the quantity factor (such as capital accumulation and labor force) but also the quality factor, namely innovation which is not merely based on increasing inputs in the industrialization process. That is, by adopting existing technology effectively and efficiently is the most important way to increase economic growth.

The innovation process is often the result of corporate and government investment in research and development (R\&D). So it can be said that $R \& D$ activities are the input of innovation. Huang and Lin (2006) explain that there are inputs and outputs in giving birth to innovation. Input factors are expenditure, labor, R\&D intensity and imported technology. While the output factor is a consequence of innovation, marketing, and development of new production and the number of licenses. So it can be concluded that R\&D activities are related to innovation, and both contribute to economic growth.

Furthermore, several studies that conducted research related to the relationship between economic growth and R\&D in OECD and non-OECD countries, showed different results. Gülmez ve Yardimcioglu (2012) conducted a relationship between R\&D expenditures and economic growth for 21 OECD countries in a long-term relationship, from 1990 to 2010. Using Pedroni and Kao the cointegration tests, the Pedroni DOLS and FMOLS tests, and the Canning and Pedroni panel causality, show that a $1 \%$ increase in R\&D expenditure accounts for about $0.77 \%$ increased long-term economic growth in all 21 OECD countries. Meanwhile, the results of research with Lamda-Pearson statistics show a two-way causality relationship between $R \& D$ expenditure and economic growth in the long run, while the average group statistical value shows a unidirectional causality oriented from economic growth to $R \& D$ in the long run. It is stated that there is a mutually significant relationship between $R \& D$ expenditure variables and economic growth (Tuna, 2015).

This opinion was also corroborated by Guloglu et.al (2012). Their results show that there is a positive and significant relationship between $\mathrm{R} \& \mathrm{D}$ and innovation, $\mathrm{R} \& \mathrm{D}$ and economic growth, and innovation and economic growth. Their research uses annual data from 1991-2007 in 13 high-income OECD countries.

Meanwhile, research by Genc et al (2010) shows that there is no causal relationship between $R \& D$ expenditure and economic growth for the 34 countries studied. The research of Sylwester (2001) examined the relationship between research and development (R\&D) and the growth rate of per capita output at the national level in $20 \mathrm{OECD}$ countries using multivariate regression. This indicates that there is no strong relationship between the two. However, if tested only on G-7 countries, it shows a positive relationship between R\&D expenditure and economic growth (Tuna, 2015).

Following in the footsteps of previous research, this study wants to examine the linkages of R\&D expenditure on economic growth when tested against 33 OECD countries, positive or negative. In this regard, our research focuses on the impact disaggregated by internet access, government researchers, computer access from home and expenditure on R\&D on GDP growth over the 2013-2019 period. 


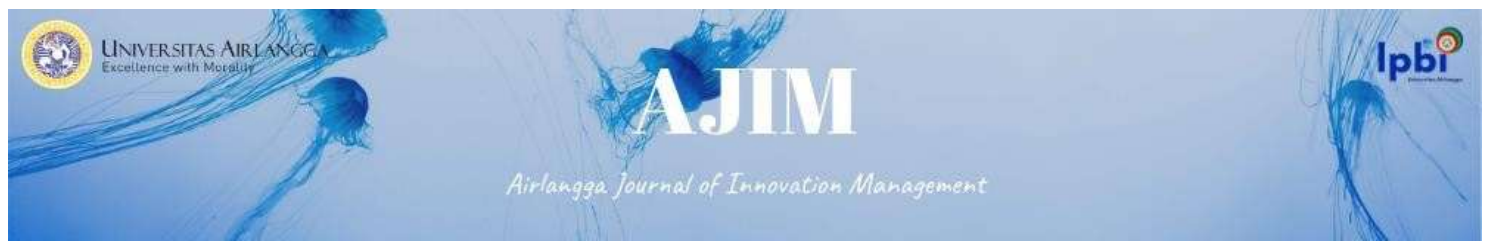

\section{LITERATURE REVIEW}

Several previous studies examining the impact of $R \& D$ expenditure on economic growth have shown two different results. First, there is research that shows there is an influence of R\&D spending on economic growth, and there is research that shows no.

For example, research by Sincere and Alerasoul (2009). They conducted research on economic growth in 30 developing countries using panel data methods in the period 2000-2006. The results showed that $\mathrm{R} \& \mathrm{D}$ spending did not have a positive effect on economic growth. The low R\&D spending in the country is because the $\mathrm{R} \& \mathrm{D}$ activities undertaken do not have a significant impact on economic growth.

Meanwhile, Genc et al (2010) investigated the relationship between R\&D and economic growth for 34 countries, applying the panel analysis method from 1997 to 2008. His research shows that there is no causal relationship between $\mathrm{R} \& \mathrm{D}$ and economic growth.

Similar to Genc, Lichtenberg's (1993) study also shows the same results. Lichtenberg conducted research on the private and public sectors for 74 countries between 1964-1989. According to the results of his research, there is a relationship between private sector $R \& D$ spending and economic growth. However, public sector R\&D spending has no effect and has a negative effect on economic growth.

Jones (1995) research also examines R\&D growth in total factor productivity (TFP) and the growth rate of the number of scientists and engineers in France, Germany, Japan and the United States. The results of his research found no evidence that these variables were positively related. Meanwhile, a research by Aghion and Howitt (1992) shows results that conflict with Jones (1995). First, increasing the complexity of technology must be linear with increasing R\&D over time to maintain a constant rate of innovation for each product. Second, an innovation in one product affects a smaller proportion of economic growth, so that the effect of proportional abundance is smaller on the aggregate stock of knowledge. Research by Scherer (1982), Griliches and Lichtenberg (1984), Aghion and Howitt (1992), and Zachariadis (2003) also provide strong evidence that US investment in R\&D and Growth in TFP is positive.

Raffo, Lhuillery\&Miotti (2008) research shows that knowledge input (R\&D or other innovation activities) is expected to produce some knowledge output (innovation), which in turn has a direct impact on economic performance (labor productivity). So, it can be concluded that R\&D and innovation are key factors for economic growth.

\section{RESEARCH METHOD}

\section{Data Types and Sources}

To answer the problem, this study uses quantitative methods. The aim is to analyze and estimate the effect of independent variables (gross domestic expenditure on R\&D, government researchers, internet access, computer access from home) on the dependent variable (economic growth) using mathematical models, theories and hypotheses. The main data source comes from the OECD. The data presented is panel data.

\section{Model and Procedure of Analysis}

The relationship of economic growth variables, gross domestic expenditure on $R \& D$, government researchers, internet access, computer access from home, were analyzed using the econometric equation of panel data. The first stage of panel data analysis is to choose the most valid model among Pooled Least Square (PLS) or also called Common Effect Model (CEM), Fixed Effect 


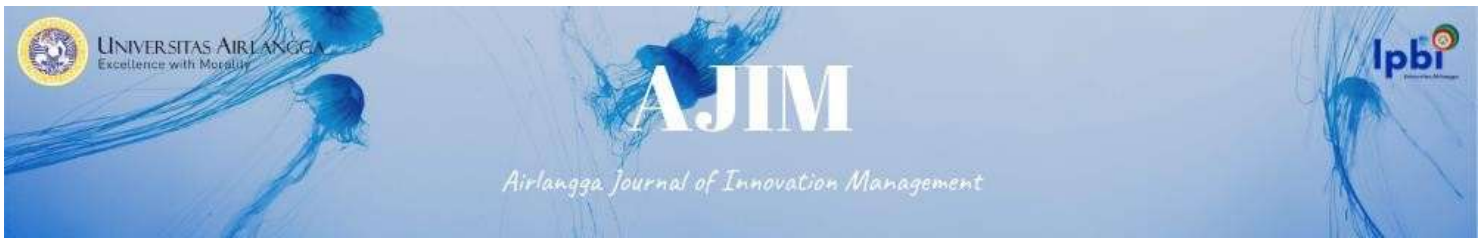

Model (FEM) and Random Effect Model (REM). From the estimation results of the three models, several assumption tests are performed to see the exact model among the three. The tests include: (i) Chow Test to determine a more appropriate model between CEM and FEM; (ii) Hausman Test to determine a more appropriate model between FEM and REM. and (iii) Breusch-Pagan Lagrangian Multiplier (LM) test to determine a more appropriate model between CEM and REM.

\section{RESULTS AND DISCUSSION}

This chapter will describe the results of the estimated coefficients of the static panel data model, namely CEM, FEM and REM. From the estimation results, it will be known which independent variable has an influence (either positive or negative effect) on the dependent variable (economic growth). Thus the next step is to provide relevant recommendations for improving the productivity of good research. As explained earlier, the panel data model consists of three estimation models, namely CEM, FEM and REM. To find out the right estimation model used in this study, three tests will be conducted, namely the Chow test, the Hausmann test and the LM test.

The first test carried out was the Chow Test, to choose the CEM or FEM method. The hypothesis used is as follows:

$\mathrm{H} 0=$ the method used is CEM

$\mathrm{H} 1=$ the method used is FEM

With the provisions of decision making, the value of Prob. Chi-square cross-section $<0.05$ then FEM selected. Conversely if $>0.05$ then the CEM will be selected.

Table 1. Chow Test

Redundant Fixed Effects Tests

Equation: Untitled

Test cross-section fixed effects

\begin{tabular}{llll}
\hline \hline Effects Test & Statistic & d.f. & Prob. \\
\hline \hline Cross-section F & 1.277549 & $(35,51)$ & 0.2093 \\
Cross-section Chi-square & 57.288245 & 35 & 0.0101
\end{tabular}

Source: Data processed (2020)

From the table 1, it can be seen that the value of Prob. Chi-square cross-section of 0.0101 or $<0.005$. This means that the right method to use is with FEM. Next, to test whether the FEM method is really appropriate to be used in this study is the Hausmann Test. The Hausman test was carried out to compare the most appropriate model between FEM and REM. Decision making criteria if Prob. $<0.05$ then the method chosen is FEM, vice versa if Prob. $>0.05$ then the selected REM.

Table 2. Hausmann Test

Correlated Random Effects - Hausman Test

Equation: FEMEQ17420

Test cross-section random effects

\begin{tabular}{llllll}
\hline \hline \multirow{2}{*}{ Test Summary } & \multicolumn{2}{c}{ Chi-Sq. } & Chi-Sq. & Prob. \\
\hline \hline & Statistic & d.f. & & \\
Cross-section random & $37^{5.4406}$ & & 4 & 50 & 0.24 \\
\hline \hline
\end{tabular}




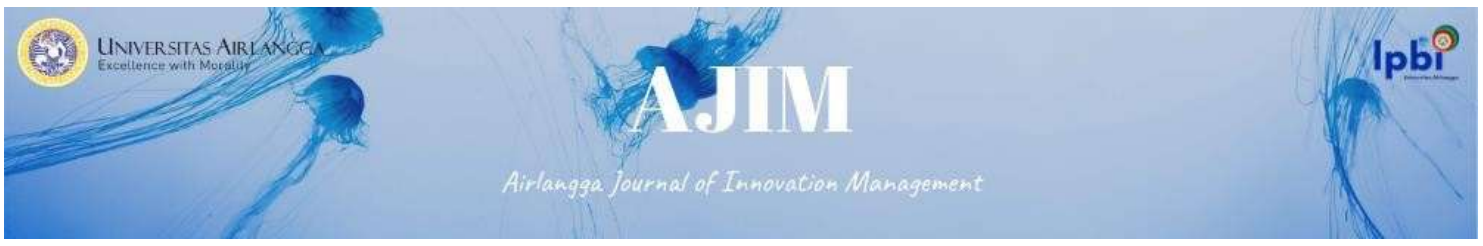

Source: Data processed (2020)

From table 2, it is known that the probability value is 0.2450 or $>0.05$, which means that the best chosen method is REM. Thus, the final test step for selecting the best method is the Lagrange Multiplier Test (LM). The LM test is performed to choose the most appropriate model between CEM and REM. The LM test is based on the Chi-Squares distribution with degrees of freedom (df) equal to the number of independent variables. If the calculated LM value is greater than the critical value of ChiSquares, the null hypothesis is rejected, which means that the right model for panel data regression in the study is REM, and vice versa. The final results of this test will determine the method chosen for statistical testing.

From the table 3, a Cross Section value of 0.7986 is obtained. It means $>0.05$ or accept $\mathrm{H} 0$ which means the best estimation method is CEM.

Table 3. Lagrange Multiplier Test

Lagrange Multiplier Tests for Random Effects

Null hypotheses: No effects

Alternative hypotheses: Two-sided (Breusch-Pagan) and one-sided

(all others) alternatives

\begin{tabular}{llll}
\hline \hline & $\begin{array}{l}\text { Test Hypothesis } \\
\text { Cross-section }\end{array}$ & Time & Both \\
\hline \hline Breusch-Pagan & $\begin{array}{lll}0.065123 \\
(0.7986)\end{array}$ & $\begin{array}{l}2.661760 \\
(0.1028)\end{array}$ & $\begin{array}{l}2.726884 \\
(0.0987)\end{array}$
\end{tabular}

Source: Data processed (2020)

Referring to the test results (chow test, hausmann test and LM test) which have been described previously, an analysis was obtained that each regression model was selected in each test. In the chow test, the chosen model is FEM, while in the hausmann test is REM and for CEM selected in the LM test. With the condition of each selected regression model, the final benchmark for the best model used is the final test results (LM test). Thus CEM was chosen as a model used to interpret panel data regression in response to research objectives.

However, because the CEM output cannot provide a better interpretation than the FEM output, this study will use FEM. This was corroborated by Buddelmeyer, Oguzoglu and Webster (2008) in the journal "Fixed Effect Bias in Data Estimator Panel" which states that FEM will remain an important matter in policy implications.

In the results of the regression table 4, it is concluded that there are three independent variables that have a significant effect on economic growth, namely gross domestic expenditure on R\&D (0.004), government researchers $(0.01)$ and internet access $(0.01)$. All three variables have a probability $<0.05$ $(5 \%)$ so that all three have simultaneous and significant effects on the dependent variable. As for the variable computer access from home no, because the probability is $>0.05$. 


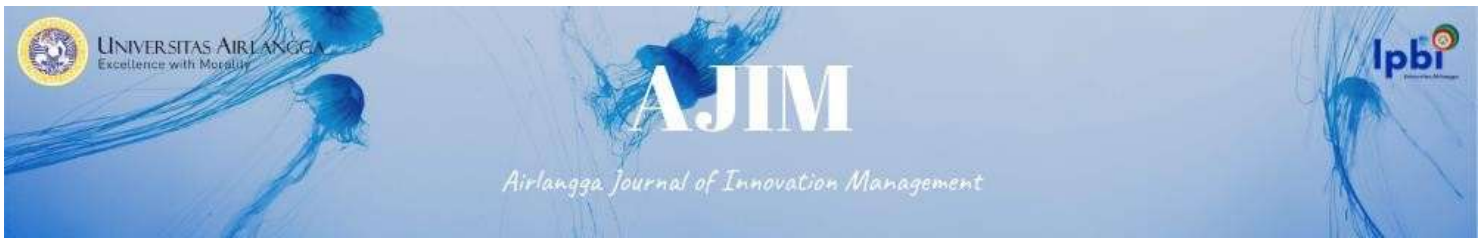

Table 4. CEM, FEM and REM Processing

\begin{tabular}{|c|c|c|c|c|}
\hline & & \multicolumn{3}{|c|}{ Estimation Method } \\
\hline \multicolumn{2}{|c|}{ Variable } & CEM & FEM & REM \\
\hline $\begin{array}{l}\text { Government Expenditure } \\
\text { on R\&D }\end{array}$ & Coefficient & $1.158505^{-}$ & 1.987547 & 1.264615 \\
\hline & T-Stat & $2.85061 \overline{2}^{-}$ & 2.944775 & 3.009392 \\
\hline & Probability & 0.0055 & 0.0049 & 0.0034 \\
\hline Government Researcher & Coefficient & $\begin{array}{r}- \\
0.105059 \\
\end{array}$ & 0.203002 & 0.114451 \\
\hline & T-Stat & 2.257251 & $2.515548^{-}$ & 2.417594 \\
\hline & Probability & 0.0265 & 0.0151 & 0.0177 \\
\hline Internet Access & Coefficient & 0.091641 & 0.201987 & 0.102110 \\
\hline & T-Stat & 1.902893 & 2.460783 & 2.034800 \\
\hline & Probability & 0.0604 & 0.0173 & 0.0450 \\
\hline $\begin{array}{l}\text { Computer Access from } \\
\text { home }\end{array}$ & Coefficient & $0.059084^{-}$ & $0.151261^{-}$ & 0.067334 \\
\hline & T-Stat & 1.369248 & 1.868746 & $\begin{array}{r}- \\
1.464978 \\
\end{array}$ \\
\hline & Probability & 0.1745 & 0.0674 & 0.1466 \\
\hline Adj R-Squared & & 0.093352 & 0.185370 & 0.105529 \\
\hline R-Squared Overall & & 0.133648 & 0.538376 & 0.132300 \\
\hline F-Stat & & 3.316700 & 1.525117 & 3.654538 \\
\hline Prob (F-Stat) & & 0.014124 & 0.078300 & 0.008482 \\
\hline
\end{tabular}

Source: Data processed (2020)

From the table 4, it can also be seen that the coefficient of determination (R-squared) is 0.5383 . That is, $53 \%$ of the independent variables are able to explain the dependent variable. While the remaining $47 \%$ is explained by other variables outside the model.

With a t-stat of -2.944775 , it indicates that the variable gross domestic expenditure for R\&D has significant and negative effect on economic growth. This means that when there is a $1 \%$ increase in gross domestic expenditure on R\&D, economic growth will decrease by $2.94 \%$. Provisional allegations, this could happen because there is a possibility that research and development activities carried out by the government are not measurable so they do not have a positive effect on economic growth. This allegation is strengthened by research conducted by Zhong, Yuan Li and Huang (2011). They conducted research on the effectiveness of R\&D investments in China. The results show that over the past two decades, R\&D investment in China has not yielded satisfactory results and contributed to economic development.

The results of this study are inversely proportional to the research conducted by Tiryakioglu (2006) who analyzed the relationship between R\&D spending and economic growth in the OECD region in 1997. The purpose of his research was to determine whether economic growth depends on 


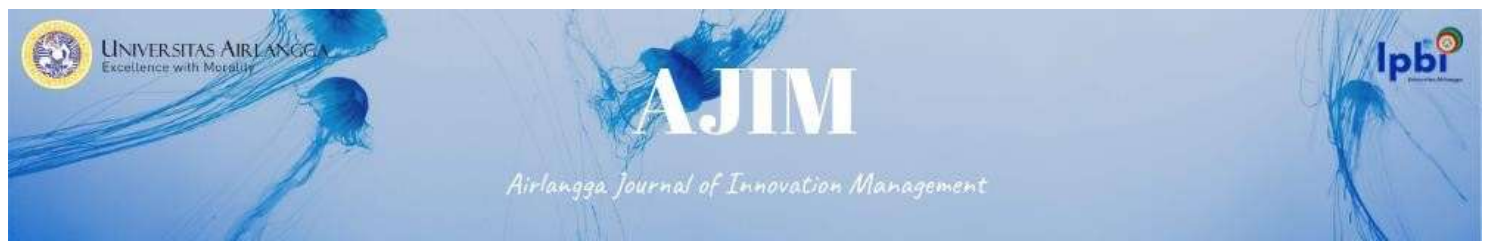

$R \& D$ expenditure, both in the short and long term. His research findings show that there is a causal relationship between $R \& D$ expenditure and economic growth.

Thus, it can be analyzed from the two different research results above that different R\&D expenditure sectors have different levels of effectiveness. This can happen because the priority programs of R\&D activities are carried out differently, so the output produced is different, depending on each R\&D activity program. This result supports Griffith et al. (2000) statement that R\&D spending plays a role in assimilating other people's research findings and its conventional role as a source of innovation. The size of the overflow depends on the R\&D activity itself.

While for government researcher variables, the t-stat obtained was -0.203002 . That is, the variable government researchers negatively and significantly influence economic growth. When there is a $1 \%$ increase in government researchers, economic growth will decrease by $0.20 \%$. It can be said, government researchers are the main actors in research in order to produce innovation. This is in line with (Huang and Lin, 2006) who suggest that the R\&D team plays an important role in business sustainability and R\&D expenditures to drive innovation. Given the important role of researchers, the $R \& D$ activities undertaken by researchers must also be based on usefulness. Beyond that, the $R \& D$ expenses that have been made will be wasted. This relationship is linear with the R\&D expenditure variables described previously.

In contrast to internet access, the t-stat of 2.460783 shows that internet access has a positive effect on economic growth. That is, if there is a $1 \%$ increase in internet access then economic growth will rise $2.46 \%$. Therefore, wide open internet access to the market will increase economic activity in various segments, including the Small and Medium Enterprises (SME) segment. Small and medium businesses can use the internet to sell or increase sales of their products through an online system.

With these conditions, it can be concluded that the increase in internet access will affect economic growth, and vice versa. This opinion is reinforced by Deloitte's research (in Tirto, 2020) which states that the cessation of a country's internet connection will be directly proportional to the decline in the value of GDP. If a country that is highly connected to the internet turns off the internet for one day, there is a loss of $\$ 23.6$ million per 10 million population in the country's GDP. While for countries that are less connected to the internet, the shutdown of the internet network for one day affects losses of $\$ 0.6$ million to $\$ 6.6$ million per 10 million population in GDP. This researches show that internet has revoluted humans life. Research and the internet will always be connected to each other, as Internet provides a way to access all kinds of information. Adegoke (2009) affirms that the Internet is also a virtual library which is seen as virtual space containing a vast amount of information and documents including books, pictures, video, graphs and musical sounds that can be consulted (Abubakar \& Diyoshak, 2015).

However, the internet as a medium for disseminating and exchanging information also faces various problems in its use, including the incompatibility between the interests of users and technology (Heaton and Brown, 1995; Allen and Retzlaff, 1998) and the information is too much and dynamic (Hicks and Tedd 1995). The risk is that a lot of time is wasted looking at information that is not relevant to work (Abubakar \& Diyoshak, 2015).

\section{CONCLUSION AND RECOMMENDATION}

The regression results of this study indicate that there are three independent variables that influence economic growth. Among them are gross domestic expenditure on $R \& D$, government researchers, and internet access. Both gross domestic expenditures for $\mathrm{R} \& \mathrm{D}$ and government researchers, have a negative effect on economic growth. With t-statistics each of -2.944775 and - 


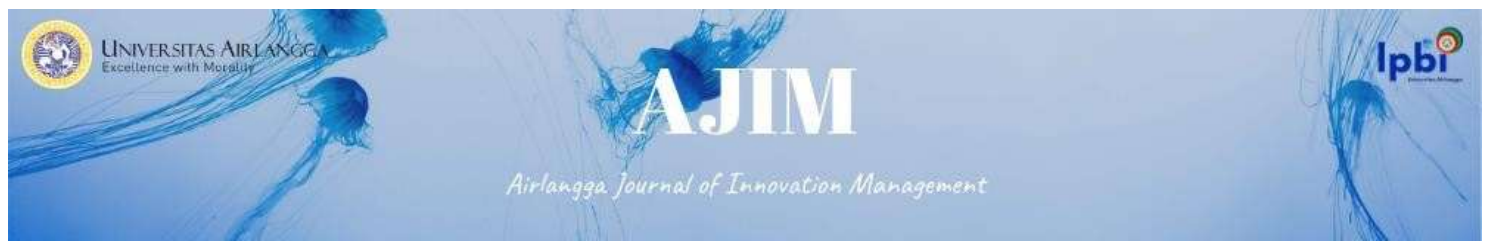

0.203002. While t-statistics for internet access are 2.460783. This shows that only internet access variables have a positive effect on economic growth. And for computer access from home, it does not affect economic growth, because the probability is 0.0674 or $>0.05$.

With the condition that internet access only has a significant and positive impact on economic growth, it means that the government must make the best use of this momentum to be able to produce research that is suitable for current and future needs, so that these results can be immediately implemented. In addition, the government must also be able to map the largest use of the internet in what fields. Thus, the research carried out can be focused on this field, with the hope of creating new innovations.

Afirmative policies made must be used to overcome short-medium term problems. Some strategies suggested improving it. Strategies suggested are: 1), improving the quality of the research. The economic structure of each country is certain that it will not allow investment if it is inefficient and produces benefits. Likewise with R\&D activities. The activities carried out must provide sustainable benefits and can bring the Indonesian state forward. 2) Government must appreciate research agenda first, then implemented it well. 3), the research agenda must be clear, both in terms of issues and techniques. This is based on the premise that R\&D activities need long-term tennis efforts, and the benefits of spending can be felt in the next 20 or 35 years. 4) The research carried out must be more substantive than formal. If policy makers take advantage of the situation for the long term when investing in R\&D activities, then an appropriate strategy is needed related to determining the criteria and components of R\&D activities. If those policies can implement as well as possible, so gross domestic expenditure activities for $\mathrm{R} \& \mathrm{D}$ are really measurable in order to encourage increased research and development activities so as to produce innovations that can improve industrial competitiveness, in effect, Indonesian economic will grow positively.

\section{REFERENCES}

Aghion, P. And Howitt, P. (1992). A Model of Growth Through Creative Destruction, Econometrica $60,323-51$.

Buddelmeyer, Oguzoglu and Webster (2008). Fixed Effect Bias in Data Estimator Panel. Discussion Paper 3487. IZA Germany.

Daniel Abubakar, Rhoda Diyoshak. (2015).Internet Connectivity and Accessibility in University Libraries: A Study of Access, Use and Problems among Faculty of Natural Sciences Students, University of Jos, Nigeria. (2015). Evidence Based Library and Information Practice, 10.4 https://www.researchgate.net/publication/295832231_Internet_Connectivity_and_Accessibility _in_University_Libraries_A_Study_of_Access_Use_and_Problems_among_Faculty_of_Natura 1_Sciences_Students_University_of_Jos_Nigeria

Kadir Tuna, Emir Kayacan, Hakan Bektaú. (2015). The Relationship Between Research \& Development Expenditures and Economic Growth: The Case of Turkey. Procedia - Social and Behavioral Sciences 195. $501-507$.

Genc, Murat Can \&Attasoy, Yesin (2010). Relationship Between R\&D Expenditure And Economic Growth: Panel Data Analysis, The Journal of Knowledge \& Knowledge Management. V. Fall.

Gene M. Grossman \& Elhanan Helpman (1994). Endogenous Innovation in The Theory of Growth. NBER Working Paper Series. Working Paper 4527.

Griffith, R., Redding, S. And Van Reenen, J. (2000). Mapping the Two Faces of R\&D: Productivity Growth in A Panel of OECD Industries. Center for Economic Policy Research, Discussion Paper 2457. 


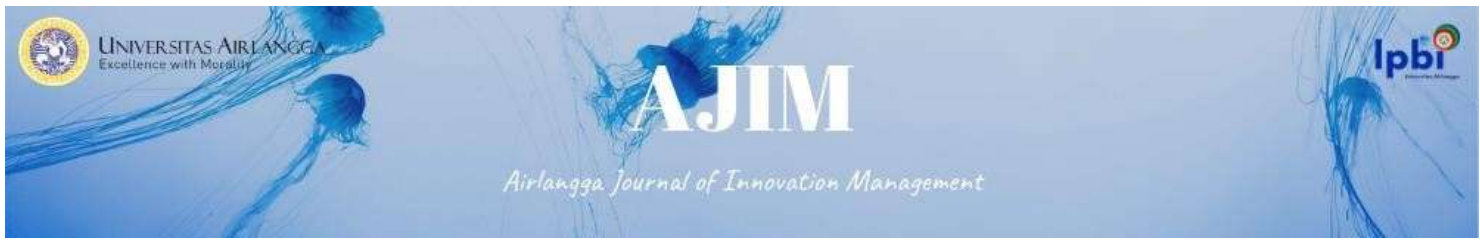

Griliches, Z. And Lichtenberg, F. (1984a). R\&D And Productivity Growth At The Industry Level: Isthere Still A Relationship?. In Z. Griliches (Ed.), R\&D, Patents, and Productivity, NBER Andchicago University Press.

Guloglu B., \&Tekin R Line. (2012). A Panel Causality Analysis of The Relationship Among Research And Development, Innovation And Economic Growth In High Income OECD Countries. Eurasion Economic Review, 2 (1). 32-47.

Huang, E., And Lin, S.C. (2006). How R\&D Management Practice Affects Innovation Performance. Industrial Management \& Data Systems, 106 (7), 966-996.

Jones, Charles I. (1995). R \& D-Based Models of Economic Growth. Journal of Political Economy, 103 (4), 759-784.

Lichtenberg, Frank R. (1993). R\&D Investment and International Productivity Differences. NBER Working Paper Series, W4161.

Raffo, J., Lhuillery, S., \&Miotti, L. (2008). Northern And Southern Innovativity: A Comparison of European and Latin American Countries Across. European Journal of Development Research, 20 (2), 219-239.

Scherer, F. (1982). Inter-Industry Technology Flows And Productivity Growth. Review of Economics And Statistics 64, 627-34.

Schumpeter, JA (1943). Capitalism, Socialism and Democracy. (6 Ed.). Rutekan. 81-84. ISBN978-0415-10762-4.

Sincere, Ahmad Jafari - Alerasoul, Seyede Monireh (2009). R\&D And Economic Growth: New Evidence From Some Developing Countries. Australian Journal of Basic And Applied Sciences. 3 (4), 3464- 3469.

Tirto. (2020). Internet yang semakin penting menopang perekonomian negara Czum. Https://Tirto.Id/Internet-Yang-Semakin-Penting-Menopang-Perekonomian-Negara-Czum

Tiryakioglu, Murad. (2006). Research And Development-Relationship Of Economic Growth : Application On Selected OECD Countries. Afyon Kocatepe University Institute Of Social Science, Afyon.

Zhong, W., Yuan, W. Li, S.X. And Huang, Z. (2011). The Performance Evaluation Of Regional R\&D Investments In China: An Application Of DEA Based On The First Official China Economic Census Data. Omega. 39 (4), 447-455. 